DOI https://doi.org/10.33766/2524-0323.86.282-293

УДК 341.232:343.123.12(477)

О. В. Краснов,

начальник оперативно-розшукового відділу

Східного регіонального

управління (з м. д. н. п. Краснопілля)

Державної прикордонної

служби України

(з м. д. н. п. Краснопілля - м. Суми, Україна)

e-mail: krasnovsasha84@gmail.com

(Dhttps://orcid.org/0000-0002-9220-4558

\title{
ПРОБЛЕМНІ ПИТАННЯ ВПРОВАДЖЕННЯ КОНЦЕПЦІЇ ІНТЕГРОВАНОГО УПРАВЛІННЯ КОРДОНАМИ В УКРАЇНІ
}

У статті розглянуто проблемні питання впровадження концепції інтегрованого управління кордонами в Україні. Висвітлено основні віхи імплементації цього європейського підходу в Україні в 2010 - 2015 роках. Наголошено на потребі розроблення нової концепції інтегрованого управління кордонами з огляду на те, що чинна концепція розрахована на період до 2020 року. Визначено інші фактори, які обгрунтовують потребу вдосконалення системи управління кордонами, серед яких - протидія терористичній діяльності та протидія транснаціональній організованій злочинності.

Ключові слова: інтегроване управління кордонами, прикордонна безпека, європейська інтеграція, транскордонна злочинність.

Постановка проблеми. Основою забезпечення належного режиму державного кордону в Україні на сьогодні є концепція інтегрованого управління кордоном. Така концепція прийнята в ЄС як сучасна модель, що дає змогу як сприяти законним переміщенням i торгівлі, так і запобігати транскордонній злочинності. Отже, упровадження цієї концепції має на меті як ефективне забезпечення прикордонної безпеки нашої держави, так i реалізацію нею політики європейської інтеграції.

В Україні діяльність з імплементації цього підходу, напрацьованого в Європейському Союзі, здійснюється з 2010 року після прийняття відповідного урядового розпорядження [1] і суттево розширено в 2015 році, коли було затверджено оновлену редакцію Концепції інтегрованого управління кордонами [2]. Реалізація останньої Концепщії розрахована на період до 2020 року. Тобто на сьогодні нагальною $є$ розробка нової Конщепції інтегрованого управління кордонами, що має базуватися на науковому підгрунті, яке б враховувало сучасні вимоги й тенденції розвитку ситуації у сфері забезпечення прикордонної безпеки.

Аналіз останніх досліджень і публікацій. Останнім часом проведено значну кількість наукових досліджень щодо питань розбудови політики держави в сфері забезпечення прикордонної безпеки. Зокрема в дисертаційному дослідженні $\quad$ В. Березенка здійснено аналіз питань конституційно-правового забезпечення режиму державного кордону, їx 
значення для формування політики в цій сфері [3]. Натомість у дисертації О. Цевельова висвітлені питання, пов'язані з формуванням політики держави у сфері забезпечення національної безпеки в цій галузі [4]. У своєму дослідженні О. Мякота розкриває питання, пов'язані 3 визначенням міжнародно-правового статусу державних кордонів України [5]. Питання міжвідомчої взаємодії суб'єктів забезпечення прикордонної безпеки розглянуто в дослідженні I. Кушнір [6]. Також суттевий інтерес викликають матеріали, викладені в опублікованій останнім часом навчальній літературі. Скажімо, у навчальному посібнику, який підготував авторський колектив [7], висвітлено основні положення політики нашої держави в цій сфері та повноваження, якими наділені суб'єкти ії реалізації. У навчальному посібнику $€$ Стрельцова та А. Притули розкрито питання застосування заходів кримінального права 3 охорони державного кордону України [8]. Питання забезпечення режиму державного кордону розглянуто в навчальному посібнику Д. Купрієнка, Ю. Дем'янюка та О. Діденка [9]. Водночас питанням впровадження інтегрованого управління кордонами в нашій країні достатньої уваги на рівні наукових досліджень не було приділено. Отже, існує потреба у формуванні наукового підгрунтя впровадження цієї концепції в Україні.

Формування цілей. Метою статті є дослідження ключових особливостей концепції інтегрованого управління кордонами та формулювання напрямів ії дальшої імплементації в нашій державі.

Виклад основного матеріалу. На початку XXI століття прослідковується зміна підходів до забезпечення безпеки державного кордону. Ризики у сфері прикордонної безпеки можуть виявитися в будь-якому місці, а не лише в межах територіальних кордонів або юрисдикції держави. Забезпечення цієї безпеки вимагає реагування на ризики там, де їх було виявлено, бажано до того моменту, поки вони реалізувалися в певні порушення. Зміна цих підходів також обумовлена збільшенням потоків людей i товарів, розширенням міжнародної торгівлі.

Виділимо низку факторів, що визначають потребу у вдосконаленні системи управління кордонами. Зокрема протидія терористичній діяльності та транснаціональній організованій злочинності обумовлює потребу в проведенні узгоджених дій на державному кордоні, у яких брали б участь різні компетентні органи на національному та міжнародному рівнях. Ефективний контроль над потоками товарів, спрямований на запобігання контрабанді, потребує гармонізації управління ризиками органів охорони державного кордону. Іншим чинником такого роду є розвиток електронної комерції. Окрім цього, потреба в забезпеченні сталого зростання світової економіки вимагає забезпечення раціонального використання ресурсів, що передбачає й оптимізацію управління кордонами. Водночас потреби в спрощенні процедур торгівлі та перетину кордону громадянами не мають ставити під загрозу питання забезпечення національної безпеки.

Належне функціонування режиму державного кордону є однією зі складових національної безпеки. Політика управління кордонами значною мірою визначає безпеку громадян на території держави, реалізацію їхніх прав і свобод, функціонування економіки. Украӥнська політика у цій сфері 
орієнтована на стандарт інтегрованого управління кордонами, розроблений у Європейському Союзі; він став реакцією на виклики глобалізації та інтенсифікації транскордонних рухів. Цей підхід орієнтований на забезпечення багатоскладової системи контролю, що розповсюджується на всю територію держави та поза тї межами, охоплюючи діяльність широкого кола суб'єктів. Ключовими складовими цього підходу є міжнародна співпраця, аналіз ризиків та інформаційний обмін на національному й міжнародному рівнях [10].

Основною метою Європейської концепщії інтегрованого управління кордонами є попередження транскордонної злочинності, разом із забезпеченням прав людини. Ії̈ сутністю є забезпечення координації та співробітництва між усіма органами, що беруть участь в охороні кордону на національному та міжнародному рівнях, 3 метою забезпечення ефективного та скоординованого управління кордонами (задля забезпечення відкритих, але контрольованих і надійних кордонів) [11].

Інтегроване управління кордонами має трирівневу структуру організації співробітництва - на внутрішньовідомочму, міжвідомчому та міжнародному рівнях, а також охоплює чотирирівневу модель управління доступом, що вміщує заходи, які проводяться в третіх країнах задля запобігання нелегальній міграції, а також співробітництво із сусідніми країнами, прикордонний контроль і контроль у зоні вільного переміщення людей.

Концепція передбачає посилення захисту зовнішніх кордонів та створення умов для ефективного обміну інформацією про можливі загрози безпеці між країнами - членами ЄС. Відповідно, основні зусилля спрямовані на зовнішні кордони ЄС. Окрім цього, значна увага приділяється розвитку взаємодії з країнами, з якими Євросоюз безпосередньо межує, серед них $є$ i Україна.

Міжнародний рівень співробітництва охоплює співробітництво на багатосторонньому рівні задля напрацювання ліпшого підходу до спільних проблем, таких, як транскордонна злочинність, нелегальна міграція, тероризм, контрабанда товарів. Це досягається через забезпечення співробітництва між компетентними органами різних країн, багатостороннього співробітництва та вдосконалення нормативно-правової бази. Зокрема, співробітництво між сусідніми країнами вміщує спільне патрулювання, координацію оперативно-розшукової діяльності, організацію спільних пунктів перетину кордону та контактних офісів, інформаційний обмін, спільну підготовку кадрів тощо. На місцевому рівні міжнародне співробітництво може здійснюватися завдяки контактам між офіційними представниками з обох сторін кордону.

Основою міжнародного співробітництва є інформаційний обмін. Для забезпечення інформаційного обміну та координації в прикордонній сфері у кожній державі ЄС створено Національні координаційні центри, які є контактними центрами для взаємодії з Європейським агентством з охорони зовнішніх кордонів країн-членів Європейського Союзу (Frontex). Frontex здійснюе інтегроване управління зовнішніми кордонами ЄС спільно 3 
уповноваженими національними органами держав-членів ЄС. Наявною тенденцією сучасного періоду є підвищення ролі Frontex і перебирання цією структурою функцій національних прикордонних відомств. Упроваджуються єдині стандарти управління зовнішніми кордонами, а також забезпечення постійного контролю та проведення аналізу ризиків. Frontex має доступ до національних інформаційних систем, що стосуються діяльності в сфері охорони кордону. На його основі створено Прикордонні команди швидкого реагування, що мають право діяти в усіх державах-членах ЄС. Ідея створення цих груп полягає у формуванні механізму, який дає змогу швидко направляти співробітників прикордонних органів країн ЄС у регіони, де відбуваються надзвичайні ситуації. Їхні члени мають право здійснювати контроль відповідно до Шенгенського кодексу про кордони. До їх функцій належить охорона кордону, перевірка документів, опитування осіб, які не мають відповідних документів, запит на інформацію у базі даних [12, с. 94 - 97].

Іншим напрямом концепції інтегрованого управління кордонами $є$ міжвідомче співробітництво на національному рівні. Відповідно до процедур і практик країн ЄС доцільним визнається розробка угод між прикордонними, митними, іншими правоохоронними, а також іншими причетними відомствами (скажімо, фітосанітарними) на центральному та регіональному рівнях з урахуванням специфічних функцій, компетенцій, потреб інформаційного обміну, порядку проведення перевірок та інших процедур.

Ця практика активно застосовується і в країнах, що не є членами $Є С$, але мають 3 ним розвинуту договірну базу. Наприклад, у країнах регіону Західних Балкан формуються так звані «оперативні центри», що забезпечують аналіз та обмін інформацією, а також надання сприяння митним і прикордонним органам у проведенні розслідувань. Вони здійснюють аналіз ризиків, визначають об'єкти для проведення контролю, а також виступають елементом зв'язування між різними відомствами, причетними до охорони кордону [12, с. 101-102].

Деяке уточнення ціеї концепщії відбулося в 2016 році. Стаття 4 оновлених Регуляційних правил ЄС щодо служби охорони кордону та берегової лінії Європейського Союзу [13] визначає компоненти європейської системи інтегрованого управління кордонами:

- прикордонний контроль, серед іншого, заходи із забезпечення законного перетину кордону, а також, у разі доцільності, попередження та виявлення транскордонної злочинності, зокрема незаконного перевезення мігрантів, жертв торгівлі людьми, тероризму, а також дій, що стосуються осіб, які потребують міжнародного захисту;

- проведення операцій з пошуку та рятування осіб, які потерпають на морі, зокрема виявлених під час здійснення моніторингових операцій;

- аналіз ризиків для внутрішньої безпеки та загроз безпеці зовнішніх кордонів;

- співробітництво між країнами-членами, що здійснюється за підтримки та координації Frontex;

- співробітництво на національному рівні в країнах-членах між відомствами, відповідальними за охорону державного кордону, а також між 
відповідними структурами ЄС, що охоплює регулярний обмін інформацією, зокрема через інформаційну систему «Європейська система моніторингу кордону» (European Border Surveillance System, EUROSUR);

- співробітництво з країнами, що не є членами ЄС, передусім із сусідніми країнами, а також із країнами, що є місцями походження чи транзиту нелегальних мігрантів;

- технічні та оперативні заходи в межах Шенгенської зони, що стосуються охорони кордону й націлені на протидію нелегальній міграції та іншим формам транскордонної злочинності;

- повернення громадян країн, що не є членами ЄС, щодо яких у країнахчленах прийнято відповідні рішення;

- використання сучасних технологій, серед яких великі інформаційні системи;

- механізм контролю за якістю впровадження системи прикордонного контролю;

- механізми забезпечення спільної діяльності, зокрема спільного фінансування.

У 2018 році Європейська комісія висунула пропозиції щодо дальшого розширення Frontex iз 1600 до 10000 співробітників. Окрім цього, передбачається суттєве розширення компетенції цього відомства, яке, фактично, виконуватиме функції охорони зовнішнього кордону ЄС у повному масштабі, діючи не лише спільно з національними структурами, а й незалежно від них. Бюджет планується розширити з 1,7 млрд євро до 10 млрд. євро в 2020 році. Також Frontex отримає додаткові повноваження щодо співробітництва 3 країнами поза межами $Є С$, зокрема й через розгортання там оперативних місій.

Цю пропозицію не підтримали уряди Угорщини, Чехії та Словаччини, до того ж керівники останніх країн загалом висловилися проти існування Агентства як непотрібного Європі [14], що викликало конфлікт серед керівників країн ЄС. Скажімо, президент Франції зазначив, що країни, які не підтримують розширення FRONTEX та єдину політику ЄС стосовно мігрантів, мають залишити Шенгенську зону й бути позбавлені доступу до структурних фондів [15]. Керівництво Австрії та Німеччини також підтримало пропозицію Єврокомісії щодо розширення особового складу та повноважень Агентства. Уважається, що таке розширення сприятиме більш ефективній боротьбі 3 нелегальною міграцією в Європу передусім у спосіб надання підтримки країнам на зовнішньому кордоні Євросоюзу.

3 огляду на підтримку цієї пропозиції більшістю країн $Є С$ можна передбачити, що вона буде реалізована, і в межах Євросоюзу буде створено наднаціональний правоохоронний орган із широкими повноваженнями та можливостями. На нормативному рівні це рішення планувалося затвердити до кінця 2018 року [16]. Реформування FRONTEX здійснюватиметься разом 3 розширенням співробітництва між правоохоронними органами та спецслужбами країн ЄС у протидії 
нелегальній міграції та іншим формам транснаціональної організованої злочинності. Наприкінці 2016 року Frontex започатковано постійну місію в Болгарії на кордоні з Туреччиною [17]. На сьогодні FRONTEX планує розгорнути польову місію в Сербії [18], що братиме участь у здійсненні контролю за переміщенням мігрантів через територію цієї країни. Проект відповідної угоди спрямовано до уряду Сербії. У подальшому такі місії може бути направлено до Чорногорії, Боснії та інших країн.

Отже, на зовнішніх кордонах ЄС сформувалася цілком нова система прикордонного контролю, що охоплює національні органи охорони кордону, спецслужби та інші правоохоронні органи, інститути Євросоюзу передусім Frontex, а також представників приватного сектору та неурядових організацій [19]. Ця система є практичним виразом концепції інтегрованого управління кордонами на загальноєвропейському рівні. Концепція інтегрованого управління кордонами спрямована на створення та підтримку балансу між ефективною охороною кордону й забезпеченням його відкритості для легального руху товарів i людей. Зокрема, вона передбачає забезпечення належного прикордонного контролю на грунті аналізу ризиків, оперативно-розшукової та інформаційно-аналітичної діяльності, ефективну протидію транскордонній злочинності, упровадження чотирирівневої моделі контролю (заходи в третіх країнах, співпраця із суміжними країнами, контроль кордону та контроль у середині держави), а також міжвідомчу співпрацю компетентних органів на національному рівні та міжнародне співробітництво.

Починаючи з 2010 року, Україна впроваджує концепцію інтегрованого управління кордонами відповідно до стандартів ЄС та його консультативної підтримки. Ця Концепція закладена в таких базових міжнародних документах, як План дій з візової лібералізації та Угода про Асоціацію між Україною та ЄС. Пріоритетами у сфері управління кордонами для України $є$ імплементація європейських стандартів, посилення міжвідомчої та міжнародної співпраці, упровадження спільного контролю та патрулювання на кордоні, чотирирівневої системи контролю за в'їздом і перебуванням іноземців, імплементація угод про реадмісію та завершення оформлення кордонів.Упровадження системи інтегрованого управління кордонами є одним 3 напрямів Угоди про асоціацію між Україною та ЄС [20]. Зокрема ст. 16 Угоди передбачає розширення співробітництва в цій сфері, що передбачає, серед іншого, розвиток оперативних заходів у сфері управління кордонами.

Однією зі складових цієї концепції є ефективна протидія транскордонній злочинності та забезпечення високого рівня внутрішньої безпеки [21]. Зазначимо, що цьому питанню на стратегічному рівні належної уваги на сьогодні не приділено. Відповідно до положень чинної Концепції інтегрованого управління 
кордонами [2] викликами в цій сфері є відсутність стратегічного підходу, брак координації між суб'єктами процесу та нові безпекові виклики, пов'язані з агресією РФ проти України. На нашу думку, серед проблем, що потребують розв'язання, треба зазначити також активізацію транскордонної злочинності, зокрема пов'язаної 3 контрабандою наркотичних засобів i психотропних речовин, підакцизних товарів, а також природних ресурсів України, серед іншого, лісу та бурштину. Чинна Концепція розрахована на період до 2020 року, тож на сьогодні нагальною є потреба розробки оновленого документа. У січні 2019 р. урядовою постановою [22] створено Міжвідомчу робочу групу з питань координації інтегрованого управління кордонами. Ії основним завданням є підготовка оновленої стратегії впровадження інтегрованого управління кордонами в нашій країні. Це передбачає як формування державної політики, так і заходів щодо пї втілення. Упровадження оновленої стратегії передбачає залучення допомоги 3 боку ЄС, що буде найбільшим проектом такого роду, який реалізовувався Європейським Союзом у сфері прикордонного менеджменту [23]. Оновлений стратегічний документ у цій сфері враховуватиме положення нормативних актів Євросоюзу та потреби реалізації політики європейської інтеграції. Водночас необхідним є і врахування специфіки безпекової ситуації в нашій країні, основними детермінантами якої є, поряд 3 агресією РФ, вплив транскордонної організованої злочинності. На нашу думку, зазначені положення мають бути відображені також у поновленому Порядку денному з питань юстиції, свободи та безпеки, що визначатиме пріоритети в співпраці між Україною та ЄС у сфері інтегрованого управління кордонами.

Висновки. Подальше впровадження концепції інтегрованого управління кордонами передбачає розробку оновленої стратегії, розрахованої на період після 2020 року. На наш погляд, така стратегія має грунтуватися на результатах аналітичної роботи, спрямованої на виявлення прогалин у попередніх подібних документах і заходах з їх реалізації. Уважаємо, що додаткова увага має бути зосереджена на питаннях протидії транскордонній злочинності, що становить загрозу національній безпеці України та стає на заваді реалізації їі євроінтеграційної політики. При цьому важливим є врахування прийнятих у 2016 році оновлених Регуляційних правил ЄС щодо служби охорони кордону та берегової лінії Європейського Союзу.

Окрім цього, важливим є виявлення загроз та ризиків, реагування на які має бути внесене до оновленої стратегії. 3 огляду на це доцільним є відзначення ініціативи Місії Європейського Союзу з прикордонної допомоги Україні та Республіці Молдова (EUBAM) зі створення міжвідомчої аналітичної групи для проведення регулярної оцінки ризиків і загроз, пов'язаних із транскордонною злочинністю в Одеській області, що стане вагомим інструментом в оцінці стану прикордонної безпеки в регіоні [24]. Уважаємо, що така практика має бути не лише 
поширена на інші регіони, а й запроваджена на загальнодержавному рівні і закріплена нормативно.

\section{Використані джерела:}

1. Про схвалення Концепції інтегрованого управління кордонами : розпорядження Кабінету Міністрів України від 27.10.2010 № 2031-р. Офіиійний вісник Украӥни. 2010. № 83. С. 29.

2. Концепція інтегрованого управління кордонами:Кабінет Міністрів України. Розпорядження від 28.10.2015 № 1149-р. Офіиійний вісник Украӥни. 2015. № 90. C. 126.

3. Березенко В. Правовий режим державного кордону України: конституційно-правові аспекти регулювання та захисту : автореф. дис. ... канд. юрид. наук : 12.00.02. Київ : Нац. акад. внутр. справ, 2017. 21 с.

4. Цевельов О. Державне реагування на загрози національній безпеці у сфері безпеки державного кордону України : автореф. дис. ... канд. наук 3 держ. упр. : 25.00.05. Хмельницький : Хмельниц. ун-т упр. та права, 2017. 20 с.

5. Мякота О. Міжнародно-правовий статус державних кордонів України : автореф. дис. ... канд. юрид. наук : 12.00.11. Харків : Нац. юрид. ун-т ім. Ярослава Мудрого, 2016. 20 с.

6. Кушнір I. Нормативно-правове забезпечення взаємодії у сфері охорони державного кордону України : автореф. дис. ... канд. юрид. наук : 12.00.07. Київ : Нац. авіац. ун-т, 2014. 19 с.

7. Політичні аспекти формування та охорони державного кордону : навч. посіб. для слухачів, курсантів та студентів ВНЗ / М. І. Кабачинський та ін. Хмельницький : Вид-во НАДПСУ, 2015.399 с.

8. Стрельцов С. Л., Притула А. М. Кримінально-правова охорона державного (митного) кордону України : навч. посіб. Одеса : Фенікс, 2015. 106 с.

9. Купрієнко Д. А., Дем'янюк Ю. А., Діденко О. В. Державна територія і державний кордон : навч. посіб. для слухачів, курсантів та студентів ВНЗ / Хмельницький : Вид-во НАДПСУ, 2014. 255 с.

10. Кравчук П., Кульчицька К., Сушко І. Людський вимір: як працює західний кордон України. Дверкапо тиюжня. 2018. №46. URL: https:/ / dt.ua/international/lyudskiy-vimiryak-pracyuye-zahidniy-kordon-ukrayini-295803_.html ( дата звернення: 26.06.2019).

11. Guidelines for integrated border management in the Western Balkans. - The International Centre for Migration Policy Development. 2007. P. 13. URL: http:/ / ww w.icmpd.org/792.html?\&tx_icmpd_pi2\%5bdocument\%5d=584\&cHash=4a3246083c (да та звернення: 26.06.2019).

12. Скоординированное управление границей: международные стандарты и правоприменительная практика: монография / О.Г. Боброва, А. Ю. Кожанков, Д. Г. Коровяковский и др. Москва: Прометей, 2017. 192 с.

13. Regulation (EU) 2016/1624 of the European Parliament and of the Council of 14 September 2016 on the European Border and Coast Guard and amending Regulation (EU) 2016/399 of the European Parliament and of the Council and repealing Regulation (EC) No 863/2007 of the European Parliament and of the Council, Council Regulation (EC) No 2007/2004 and Council Decision 2005/267/EC. Official Journal of the European Union. 16.9.2016. L 251/1. URL : https:// eurlex.europa.eu/legacontent /EN/TXT/HTML/?uri $=$ CELEX:32016R1624 \& from $=$ EN 
14. Gotev G. Czech, Slovak premiers bristle at beefing up of Frontex. EURACTIV.com with Reuters. 18.09.2018. URL: https://www.euractiv.com/section/ future-eu/news/czech-slovak-premiers-bristle-at-beefing-up-of-frontex.

15. Barigazzi J. Macron: EU migration holdouts should be booted out of Schengen. 20.09.18. URL: https:/ / www.politico.eu/article/emmanuel-macron-eu-migrationfrontex-holdouts-hungary-viktor-orban-should-be-booted-out-of-schengen.

16. Salzburg summit presses for bigger Frontex mandate // Nikolaj Nielsen, Eszter Zalan. 21.09.18. URL: https:/ / euobserver.com/migration/142917.

17. Katsarova B. Launch of the European Border and Coast Guard. 06.10.2016. URL: http:/ / europa.eu/rapid/press-release_AC-16-3828_en.htm.

18. Rudic F. Frontex to Help Serbia Manage Migrant Challenge. - Balkan Insight. 20.09.18. URL: http:/ / www.balkaninsight.com/en/article/serbia-eu-initial-anagreement-on-border-protection-09-20-2018.

19. Andersson R. Europe's failed 'fight' against irregular migration: ethnographic notes on a counterproductive industry. 09.02.2016. URL : https:// doi.org/10.1080/1369 183X.2016.1139446.

20. Угода про асоціацію між Україною, з однієї сторони, та Європейським Союзом, Європейським співтовариством 3 атомної енергії і їхніми державамичленами, з іншої сторони. Офіційний вісник України. 2014. № 75. том 1. С. 83. URL: https://zakon.rada.gov.ua/laws/show/984_011 (дата звернення:26.06.2019).

21. Іванна Климпуш-Цинцадзе: Уповноважені відомства протягом місяця мають підготувати пропозиції до проекту Національної стратегії управління кордонами. 13.03.2019. URL: https://eu-ua.org/novyny/ivanna-klympush-cyncadze-upovnovazhenividomstva-protyagom-misyacya-mayut-pidgotuvaty (дата звернення: 26.06.2019).

22. Про утворення міжвідомчої робочої групи 3 питань координації інтегрованого управління кордонами : постанова Кабінету Міністрів України № 83. 30.01.2019. Офіційний Вісник Украӥни. 2019. № 17. С. 28.

23. Вадим Троян: В Україні триває активний розвиток інтегрованого управління кордонами Департамент комунікації МBC України. 31.01.2019. URL : https://mvs.gov.ua/ua/news/17911_Vadim_Troyan_V_Ukraini_triva_aktivniy_rozv itok_integrovanogo_upravlinnya_kordonami.htm (дата звернення: 26 .06. 2019).

24. Голова Держприкордонслужби Петро Цигикал зустрівся з Главою Місії EUBAM Славоміром Піхором / Державна прикордонна служба України, 13.03.19. URL: https:/ dpsu.gov.ua/ua/Golova-Derzhprikordon sluzhbi Petro Cigikal zustrivsya -z-Glavoyu-Misii-EUBAM-Slavomirom-Pihorom (дата звернення: 26.06.2019).

\section{References:}

1. Pro skhvalennia Kontseptsii intehrovanoho upravlinnia kordonamy [On Approval of the Integrated Border Management Concept] : rozporiadzhennia Kabinetu Ministriv Ukrainy vid 27.10.2010 . № 2031-p [in Ukrainian].

2. Kontseptsiia intehrovanoho upravlinnia kordonamy [The Integrated Border Management Concept] : Kabinet ministriv Ukrainy. Rozporiadzhennia vid 28.10.2015. № 1149-p [in Ukrainian].

3. Berezenko V. Pravovyi rezhym derzhavnoho kordonu Ukrainy: konstytutsiinopravovi aspekty rehuliuvannia ta zakhystu [Legal regime of the state border of Ukraine: constitutional and legal aspects of regulation and protection] : avtoref. dys. ... kand. yuryd. nauk : 12.00.02. Kyiv : Nats. akad. vnutr. sprav, 2017. 21 p. [in Ukrainian]. 
4. Tsevelov O. Derzhavne reahuvannia na zahrozy natsionalnii bezpetsi u sferi bezpeky derzhavnoho kordonu Ukrainy [State Response to Threats to National Security in the Area of Security of the State Border of Ukraine]: avtoref. dys. ... kand. nauk z derzh. upr. : 25.00.05. Khmelnytskyi : Khmelnyts. un-t upr. ta prava, 2017. 20 p. [in Ukrainian].

5. Miakota O. Mizhnarodno-pravovyy status derzhavnykh kordoniv Ukrainy [International law and the status of the state borders of Ukraine]: avtoref. dys. ... kand. yuryd. nauk : 12.00.11. Kharkiv : Nats. yuryd. un-t im. Yaroslava Mudroho, 2016. 20 p. [in Ukrainian].

6. Kushnir I. Normatyvno-pravove zabezpechennia vzaiemodii u sferi okhorony derzhavnoho kordonu Ukrainy [Regulatory and legal framework of cooperation in the field of protection of the state border of Ukraine]: avtoref. dys. ... kand. yuryd. nauk : 12.00.07. Kyiv : Nats. aviats. un-t, 2014. 19 p. [in Ukrainian].

7. Politychni aspekty formuvannia ta okhorony derzhavnoho kordonu [Political Aspects of Formation and Protection of the State Border]: navch. posib. dlia slukhachiv, kursantiv ta studentiv VNZ / M. I. Kabachynskyi ta in. Khmelnytskyi : Vyd-vo NADPSU, 2015. 399 p. [in Ukrainian].

8. Streltsov Ye. L., Prytula A. M. Kryminalno-pravova okhorona derzhavnoho (mytnoho) kordonu Ukrainy [Criminal law protection of the state (customs) border of Ukraine]: navch. posib. Odesa : Feniks, 2015. 106 p. [in Ukrainian].

9. Kupriienko D. A., Demianiuk Yu. A., Didenko O. V. Derzhavna terytoriia i derzhavnyi kordon [State Territory and State Border]: navch. posib. dlia slukhachiv, kursantiv ta studentiv VNZ /. Khmelnytskyi : Vyd-vo NADPSU, 2014. 255 p. [in Ukrainian].

10. Kravchuk P., Kulchytska K., Sushko I. Liudskyi vymir: yak pratsiuie zakhidnyi kordon Ukrainy [Human Dimension: How Does the Western Border of Ukraine Work?]. Dzerkalo tyzhnia. 2018. № 46. URL: https://dt.ua/international/lyudskiy-vimir-yakpracyuye-zahidniy-kordon-ukrayini-295803_html. [in Ukrainian].

11. Guidelines for integrated border management in the Western Balkans. - The International Centre for Migration Policy Development. 2007. P. 13. URL: http: // www.icmpd.org/792.html?\&tx_icmpd_pi2\%5bdocument\%5d=584\&cHash=4a3246083c.

12. Skoordynyrovannoe upravlenye hranytsei: mezhdunarodnie standarti y pravoprymenytelnaia praktyka [Coordinated Border Management: International Standards and Law Enforcement Practice]: monohrafyia / O. H. Bobrova, A. Yu. Kozhankov, D. H. Koroviakovskyi y dr. Moskva: Prometei, 2017. 192 p. [in Russian].

13. Regulation (EU) 2016/1624 of the European Parliament and of the Council of 14 September 2016 on the European Border and Coast Guard and amending Regulation (EU) 2016/399 of the European Parliament and of the Council and repealing Regulation (EC) No 863/2007 of the European Parliament and of the Council, Council Regulation (EC) No 2007/2004 and Council Decision 2005/267/EC. Official Journal of the European Union. 16.9.2016. L 251/1. URL:https://eurlex.europa.eu/legalcontent/EN/TXT/HTML/?uri $=$ CELEX:32016R1624\&from $=$ EN.

14. Gotev G. Czech, Slovak premiers bristle at beefing up of Frontex. EURACTIV. com with Reuters.18.09.2018. URL: https://www.euractiv.com/section/future$\mathrm{eu} /$ news/czech-slovak-premiers-bristle-at-beefing-up-of-frontex.

15. Barigazzi J. Macron: EU migration holdouts should be booted out of Schengen. 20.09.18. URL: https://www.politico.eu/article/emmanuel-macron-eu-migrationfrontex-holdouts-hungary-viktor-orban-should-be-booted-out-of-schengen.

16. Salzburg summit presses for bigger Frontex mandate // Nikolaj Nielsen, Eszter Zalan. 21.09.18. URL: https:/ / euobserver.com/migration/142917. 
17. Katsarova B. Launch of the European Border and Coast Guard. 06.10.2016. URL: http:/ / europa.eu/rapid/press-release_AC-16-3828_en.htm.

18. Rudic F. Frontex to Help Serbia Manage Migrant Challenge. - Balkan Insight. 20.09.18. URL: http://www.balkaninsight.com/en/article/serbia-eu-initial-anagreement-on-border-protection-09-20-2018.

19. Andersson R. Europe's failed 'fight' against irregular migration: ethnographic notes on a counterproductive industry.09.02.2016.URL:https:// doi.org/10.1080/136918 3X.2016.1139446.

20. Uhoda pro asotsiatsiiu mizh Ukrainoiu, z odniiei storony, ta Yevropeiskym Soiuzom, Yevropeiskym spivtovarystvom $\mathrm{z}$ atomnoi enerhii i yikhnimy derzhavamychlenamy, z inshoi storony. Ofitsiinyi visnyk Ukrainy. 2014. № 75. tom 1. P. 83. URL: https://zakon.rada.gov.ua/laws/show/984_011. [in Ukrainian].

21. Ivanna Klympush-Tsyntsadze: Upovnovazheni vidomstva protiahom misiatsia maiut pidhotuvaty propozytsii do proektu Natsionalnoi stratehii upravlinnia kordonamy. 13.03.2019. URL: https://eu-ua.org/novyny/ivanna-klympush-cyncadzeupovnovazheni-vidomstva-protyagom-misyacya-mayut-pidgotuvaty. [in Ukrainian].

22. Pro utvorennia mizhvidomchoi robochoi hrupy $\mathrm{z}$ pytan koordynatsii intehrovanoho upravlinnia kordonamy [On the establishment of an interdepartmental working group on coordinating integrated border management] : Postanova Kabinetu Ministriv Ukrainy № 83. 30.01 .2019 r. Ofitsiinyi visnyk Ukrainy. 2019. № 17. P. 28. [in Ukrainian].

23. Vadym Troian: V Ukraini tryvaie aktyvnyi rozvytok intehrovanoho upravlinnia kordonamy [In Ukraine, active development of integrated border management continues] // Departament komunikatsii MVS Ukrainy. 31.01.2019. URL: https://mvs.gov.ua/u a/news/17911_Vadim_Troyan_V_Ukraini_triva_aktivniy_rozvitok_integrovanogo_upr avlinnya_kordonami.htm. [in Ukrainian].

24. Holova Derzhprykordonsluzhby Petro Tsyhykal zustrivsia z Hlavoiu Misii EUBAM Slavomirom Pikhorom. - Derzhavna prykordonna sluzhba Ukrainy, 13.03.19. URL: https:/ / dpsu.gov.ua/ua/Golova-Derzhprikordonsluzhbi-Petro Cigikal zustrivsya -z-Glavoyu-Misii-EUBAM-Slavomirom-Pihorom. [in Ukrainian].

Стаття надійшла до редколегї 13.04.2019

Краснов А. В., начальник оперативно-разыскного отдела Восточного регионального управления (с м. д. н. п. Краснополье)

Государственной пограничной службы Украины (н. п. Краснополье - г. Сумы, Украина)

\section{ПРОБЛЕМНЫЕ ВОПРОСЫ ВНЕДРЕНИЯ КОНЦЕПЦИИ ИНТЕГРИРОВАННОГО УПРАВЛЕНИЯ ГРАНИЦАМИ В УКРАИНЕ}

В статье рассматриваются проблемные вопросы внедрения концепщии интегрированного управления границами в Украине. Освещены основные вехи имплементации этого европейского подхода в Украине в 2010 и 2015 годах. Отмечается необходимость разработки новой конщепци интегрированного управления границами, учитывая, что действующая концепщия рассчитана на период до 2020 года. Определяются другие факторы, которые обосновывают необходимость 
совершенствования системы управления границами, среди которых - противодействие террористической деятельности и противодействие транснациональной организованной преступности.

Ключевые слова: интегрированное управление границами, пограничная безопасность, европейская интеграция, трансграничная преступность.

Krasnov O., Head of the Operations and Investigation Department of the Eastern Regional Directorate State Border Service of Ukraine (Krasnopolye NP - Sumy, Ukraine)

\section{PROBLEM ISSUES IN THE IMPLEMENTATION OF THE CONCEPT OF INTEGRATED BORDER MANAGEMENT IN UKRAINE}

The article discusses the issues of implementation of the concept of integrated border management in Ukraine. It is noted that the Ukrainian policy in this area is focused on the standard of integrated border management, developed in the European Union. The main milestones of the implementation of this European approach in Ukraine in 2010 and 2015 are highlighted. There is a need to develop a new concept of integrated border management, given that the current concept is designed for the period up to 2020. Other factors are identified that justify the need to improve the border management system. Among them, including countering terrorist activities and countering transnational organized crime. The three-tier structure of the organization of cooperation (internal, interdepartmental, international) has been studied. The fourtier access control model was analyzed, which includes the following measures: 1) measures taken in third countries to counteract illegal migration; 2) cooperation with neighboring countries; 3) border control; 4) control in the area of free movement of people.

The author analyzes the specifics of the functioning of the FRONTEX agency, its tasks and prospects for further development, the role of Ukraine in the work of this organization. It was concluded that a completely new border control system was formed at the external borders of the European Union, which includes national border guard agencies, special services and other law enforcement agencies, institutions of the European Union, as well as representatives of the private sector and non-governmental organizations.

It is noted that one of the constituent parts of the concept is the effective counteraction to cross-border crime and ensuring a high level of internal security. The author points out that recently, Ukraine faces new security challenges, which are caused by armed aggression from the Russian Federation. Among other problems, the intensification of cross-border crime related to the smuggling of narcotic substances, psychotropic substances, excisable goods, and natural resources is outlined.

Key words: integrated border management, border security, European integration, cross-border crime. 